\title{
Radiológiai osztályon dolgozó szakdolgozók kiégési szintje Magyarországon
}

\author{
Sipos Dávid ${ }^{1,2,3}$ - Varga Veronika ${ }^{1}$ - Pandur Attila András ${ }^{1}$ \\ Kedves András ${ }^{2,3}$. Petőné Csima Melinda dr. ${ }^{1}$. Cseh Szabolcs ${ }^{1}$ \\ Betlehem József dr. ${ }^{1}$ - Moizs Mariann dr. ${ }^{4}$ - Repa Imre dr. ${ }^{1,3}$ \\ Kovács Árpád dr. ${ }^{1,2,3}$
}

\author{
${ }^{1}$ Pécsi Tudományegyetem, Egészségtudományi Kar, Doktori Iskola, Pécs \\ ${ }^{2}$ Pécsi Tudományegyetem, Egészségtudományi Kar, Diagnosztikai Intézet, Pécs \\ ${ }^{3}$ Somogy Megyei Kaposi Mór Oktató Kórház, Dr. Baka József Diagnosztikai, \\ Onkoradiológiai, Kutatási és Oktatási Központ, Kaposvár \\ ${ }^{4}$ Somogy Megyei Kaposi Mór Oktató Kórház, Kaposvár
}

\begin{abstract}
Bevezetés: A segítő szakmákban dolgozó szakembereket veszélyeztető kiégésnek széles körű negatív hatásai lehetnek, ami a betegellátás minőségét és az egészségügyi rendszer hatékonyságát is befolyásolhatja.

Célkitüzés: A kutatás célja volt feltárni, hogy a magyarországi radiológiai osztályon dolgozó szakdolgozókat milyen mértékben veszélyezteti a kiégés.

Módszer: Kvantitatív, keresztmetszeti, leíró kutatás keretében az adatgyüjtésre 2018. június-szeptember intervallumban online felületen megosztott kérdőív segítségével, radiológiai osztályon dolgozó szakdolgozók körében került sor egyszerü, nem véletlenszerü mintavétel alkalmazásával, anonim módon. A saját szerkesztésú kérdőív a szociodemográfiai és a munkavégzés jellegével kapcsolatos jellemzók mellett a Maslach Burnout Inventory (MBI) nemzetközileg validált kérdőívet is tartalmazta.

Eredmények: Az adatok tisztítását követően összesen 404 fő válaszait vontuk be a statisztikai elemzésbe. A többségében megyei kórházakban alkalmazott szakdolgozók átlagosan 18,3 éve (SD 13,7) dolgoznak az egészségügyi ellátórendszerben. A kiégésnek a deperszonalizáció és emocionális kimerülés dimenziójában a minta enyhén emelkedett értékű kiégést mutat. Az iskolai végzettség, az életkor és az egészségügyben eltöltött évek száma szignifikánsan befolyásolta mindhárom, kiégéssel kapcsolatos dimenziót $(\mathrm{p} \leq 0,05)$. A 31-35 éves korcsoport és a 16-20 éve a pályán lévő válaszadók tekinthetók a legveszélyeztetettebb csoportnak a kiégés mindhárom dimenziójában. Az MSc-végzettséggel rendelkezők emocionális kimerülési értéke szignifikánsan alacsonyabbnak bizonyult társaikéhoz viszonyítva.

Következtetés: A deperszonalizáció és az emocionális kimerülés emelkedett értéke jelző értékkel bírhat a munkáltatók számára. A kapott eredmények a nemzetközi szakirodalomban leírtakkal jól korrelálnak.
\end{abstract}

Orv Hetil. 2019; 160(27): 1070-1077.

Kulcsszavak: radiográfus, radiológia, kiégés, Maslach Kiégés Leltár

\section{Burnout level among radiology department workers in Hungary}

Introduction: Burnout can have a wide negative impact on the quality and the effectiveness of the health care system. The aim of our research was to assess the burnout level of the radiology department workers in Hungary.

Method: Our quantitative, cross-sectional, descriptive data collection lasted from June to September 2018 using an online questionnaire. Simple, non-random sampling was carried out among radiology department workers in Hungary. In addition to our self-made questionnaire which included socio-demographic and work-related questions, an internationally validated Maslach Burnout Inventory questionnaire was sent out.

Results: After data cleaning, a total number of $404(\mathrm{n}=404)$ respondents were included in the statistical analysis. The majority of the respondents works in county hospital, the average year spent in the healthcare system was 18.3 (SD 13,7). The sample's values at the depersonalization and emotional exhaustion dimension were slightly elevated in contrast to the average values. Educational level, age and years spent in the healthcare system had a significant influence on all the three dimensions of burnout $(\mathrm{p} \leq 0.05)$. The group of workers being $31-35$ years old and the group 
of those who spent 16-20 years in the healthcare system are considered to be the most compromised groups in all the three dimensions of burnout. Respondents with master degree had significantly lower emotional exhaustion values than their colleagues.

Conclusion: The increased value of the depersonalization and the emotional exhaustion can be an indicator for employers. Our results are similar like described in the international literature.

Keywords: radiographer, radiology, burnout, Maslach Burnout Inventory

Sipos D, Varga V, Pandur AA, Kedves A, Petőné Csima M, Cseh Sz, Betlehem J, Moizs M, Repa I, Kovács Á. [Burnout level among radiology department workers in Hungary]. Orv Hetil. 2019; 160(27): 1070-1077.

(Beérkezett: 2019. február 19.; elfogadva: 2019. március 9.)

\section{Rövidítések}

$\mathrm{AI}=($ artificial intelligence $)$ mesterséges intelligencia; ANOVA $=($ analysis of variance $)$ varianciaanalízis $; \mathrm{CT}=($ computed tomography) komputertomográfia; DSA = digitális szubtrakciós angiográfia MBI $=($ Maslach Burnout Inventory $)$ Maslach Kiégés Leltár; $\mathrm{MR}=($ magnetic resonance $)$ mágneses rezonancia; MRAE $=$ Magyar Radiográfusok Egyesülete $;$ MSc $=($ magister scientix) mesterképzés; PET = (positron-emission tomography) pozitronemissziós tomográfia; $\operatorname{Rtg}=$ röntgen; $\mathrm{SD}=$ standard deviáció; SPSS = (statistical package for the social sciences) statisztikai csomag a társadalomtudományok számára; $\mathrm{UH}=$ ultrahangvizsgálat

A munkahelyi kiégés (burnout) gyakran fordul elő az egészségügyi ellátórendszerben dolgozók körében, mely jelenség hátterében húzódó okok felderítésére számos kutatás irányult a közelmúltban. Az egészségügyi szakemberek munkájuk során számos pszichológiai, fizikai és szociális problémával küzdő beteggel kerülnek kapcsolatba, ami potenciálisan több stresszt idézhet elő [1]. A munkahelyi stressz Maslach és Jackson szerint emocionális kimerültséghez, elszemélytelenedéshez vezethet, ami a személyes hatékonyság alacsony szintjével együtt kiégést (burnout) okozhat [2].

A burnout negatív hatással lehet az egyénre, a gondozásra szoruló betegekre, a munkatársakkal való kapcsolatokra és a hatékony egészségügyi ellátásra [3].

Mivel a burnout folytonos, egymással kapcsolatban álló ciklusokból álló folyamat, melyet stresszorok váltanak ki, amennyiben a dolgozó stresszkezelő módszerei kudarcot vallanak, kialakul a krónikus fizikai és érzelmi kimerülés állapota [4].

A folyamatosan megújuló technológia forradalmasította a radiológiai ellátást, ezzel együtt az egészségügyi ellátás során szerepe egyre hangsúlyosabbá vált. A diagnosztika területén bekövetkező fejlődés felgyorsította az egységnyi idő alatt elvégezhető felvételek számát, ami nagyobb munkahelyi megterheléshez vezetett. A munkavégzés során tapasztalt ingerek hozzájárulhatnak a kiégés mértékének emelkedéséhez.

Számos munkahelyi sajátosság járulhat hozzá a kiégéshez, ilyen sajátosság például az adminisztratív feladatok elvégzése, a hosszú munkaidő vagy az orvosírnoki fel- adatkör ellátása. A radiológiai asszisztensek szakmai sajátosságához sorolható az autonómiának és az előrelépésnek a hiánya, ami hosszú távon nagyban hozzájárulhat az egyén kiégési szintjéhez [5]. A kórházban dolgozó kollégák és a betegek részéről tapasztalt megbecsülés hiánya, valamint a nem megfelelő javadalmazás mind felelőssé tehető a jelenség kialakulásáért. Nem szabad megfeledkezni a hivatással járó nagyfokú érzelmi involválódásról sem, hiszen a radiológiai asszisztensek a daganatos betegek és a különböző traumás elváltozások kapcsán kórházi ellátást igénylők ellátásában is részt vesznek, mely betegségcsoportokban gyakran a legfiatalabb korosztály is érintett [6].

A kiégés veszélye az egészségügyi ellátórendszerben dolgozó szakembereket fokozottan fenyegeti, mely jelenség mögött az irodalmi adatok szerint a következő stresszorok mutatkoznak fó prediktorként: nem, életkor, munkában eltöltött idő, másodállás, munkakör, munkahelyi elégedettség és családi összetétel. A kapcsolódó szakirodalom a nők körében tapasztalt emelkedett, kiégéssel kapcsolatos értékekről számol be, aminek hátterében a nők alacsonyabb stressztưrő képessége áll. Emelkedett értéket mutattak az egyedülálló egészségügyi dolgozók adatai is, továbbá összefüggés mutatkozott az egészségügyi ellátásban eltöltött idő és a kiégés szintje között is $[7,8]$.

\section{Célkitüzés}

Figyelembe véve a stressz és a kiégés lehetséges negatív következményeit, a radiológiai osztályok környezetében a foglalkozási kiégés prevalenciájára vonatkozó további információkra van szükség. Eredményeinket összevetve a korábban publikált, a radiográfia területén dolgozó szakemberek kiégését feltáró vizsgálatokkal, szakirodalmi kutatásokat végeztünk a PubMed-en a „radiology”, „burnout”, „Maslach”, „radiography/radiographer” kulcsszavak alkalmazásával.

Jelenlegi ismereteink alapján Magyarországon a radiológiai osztályokon dolgozó szakemberek foglalkozási kiégéséről a szabványosított és validált Maslach Burnout Inventory (MBI) kérdốiv segítségével még nem történt állapotfelmérés. Kutatásunk célja az említett szakdolgo- 
zói kör kiégési szintjének felmérése volt, továbbá a jelenség mögött húzódó munkahelyi sajátosságokkal kapcsolatban álló okok elemzése.

\section{Módszer}

Kutatásunk típusát tekintve keresztmetszeti, leíró kutatás, mely célirányos, nem véletlenszerü mintavétellel valósult meg. A radiológiai osztályon dolgozó szakdolgozók kiégési szintjének vizsgálatára irányuló felmérés a Magyar Radiográfusok Egyesületének (MRAE) jóváhagyásával és támogatásával valósult meg. Az egyesület rendszerében regisztrált közel 3000, radiológiai osztályon dolgozó szakdolgozó e-mail-címeit használtuk az online kérdőívek célba juttatásához. A kérdőív az e-mailcímeken kívül a legismertebb közösségi oldal dedikált magyar szakmacsoportjaiban 2018 júniusától 2018 szeptemberéig volt elérhető.

Az alapvetô szociodemográfiai adatokon kívül azonosításra alkalmas adatokat nem gyújtöttünk, a szociodemográfiai jellemzők mellett a kérdóív számos, munkavégzéssel kapcsolatos kérdést tartalmazott. A radiográfia területén dolgozó szakdolgozók kiégésének felmérésére a nemzetközileg validált Maslach Kiégés Leltárt alkalmaztuk. A felmérés érzékeny és önreflexiós jellege miatt a kutatás során fokozottan ügyeltünk a válaszadók anonimitására.

\section{Statisztikai analizis}

Az adatfeldolgozás az SPSS 24.0 verziójú statisztikai szoftver (IBM Corporation, Armonk, NY, Amerikai Egyesült Államok [USA]) és a Microsoft Excel 2010-es verzió (Microsoft Corporation, Redmond, WA, USA) segítségével valósult meg. A statisztikai elemekre tekintettel leíró statisztikát, egymintás t-próbát, varianciaanalízist (ANOVA), Kruskal-Wallis-tesztet alkalmaztunk 95\%-os valószínűségi tartományban $(\mathrm{p} \leq 0,05)$.

\section{Maslach Burnout Inventory - Maslach Kiégés Leltár (MBI)}

A 22 tételből álló kérdőív a deperszonalizáció, az érzelmi kimerülés és a személyes hatékonyság dimenziókra vonatkozik. Minden egyes tételnél 7 fokozatú Likert-skálán jelölhette a válaszadó, hogy az adott válasz mennyire jellemző saját magára nézve. A skálaértékek a következők voltak: 1) soha, 2) évente többször, 3) havonta egyszer, 4) havonta többször, 5) hetente egyszer, 6) hetente többször, 7) minden nap [9-12].

A személyes hatékonyságra vonatkozó állítások esetén az alacsony, míg az érzelmi kimerültségre, valamint a deperszonalizációra vonatkozó állítások esetén a magas pontszám jelezhet különböző mértékű kiégést.

A rövidített MBI-hez kapcsolódó kérdések mellett szociodemográfiai kérdéseket tartalmazó saját szerkesz- tésű kérdéssort is csatoltunk, mely javarészt munkahelyi sajátosságokkal, családi összetétellel, végzettséghez köthető szakmai elhivatottsággal kapcsolatos kérdéseket tartalmazott.

\section{Eredmények}

Az online kérdőívet összesen $404(\mathrm{n}=404)$ fö töltötte ki, akik közül 189 (n = 189) a Magyar Radiográfusok Egyesületének tagja volt. A válaszadók 28\%-a (n = 113) megyei kórházban dolgozik. Átlagéletkoruk a kérdőív kitöltésének idópontjában 40,08 év volt $(S D=12,181$; range 22-70). Nemi megoszlás tekintetében a női válaszadók voltak többségben (férfi $\mathrm{n}=57$, nő $\mathrm{n}=347$ ). A válaszadók több mint fele $(\mathrm{n}=256)$ házastársával/élettársával és gyermekével él egy háztartásban, s viszonylag magas az egyedülállók aránya is $(\mathrm{n}=110)$. Iskolai végzettségüket tekintve elmondható, hogy 10,6\%-uk (n = 43 ) rendelkezett középiskolai végzettséggel, 30,4\%-uk ( $\mathrm{n}=123$ ) felsőfokú szakképesítéssel, 56,2\%-uk $(\mathrm{n}=227)$ föiskolai vagy felsőfokú alapképzésben szerzett oklevéllel, továbbá a megkérdezettek 2,7\%-a $(\mathrm{n}=11)$ rendelkezett egyetemi diplomával a kérdőív kitöltésének időpontjában A szakmai közérzetre, ezzel együtt a kiégésre vonatkozó kutatások rámutatnak arra az összefüggésre, hogy a munkavégzésért járó jövedelem meghatározza a szakmai közérzetet, ezzel együtt befolyásolhatja a kiégés szintjét $[10,13]$. A kutatási eszköz összeállítása során ezért fontosnak tartottuk szerepeltetni az anyagi helyzettel kapcsolatos kérdéseket is. A válaszadók 56,4\%-a ( $\mathrm{n}=228)$ megél a fizetéséből, de keveset tud félretenni, $8,4 \%$-uk $(\mathrm{n}=34)$ pedig úgy érzi, jövedelme arra sem elég, hogy megéljen belőle (1. táblázat).

A válaszadók 22,5\%-a $(\mathrm{n}=91)$ rendelkezik másodállással, mely közel 90\%-ban az egészségügyhöz, orvosi képalkotáshoz köthető (2. táblázat). A munkavállalók $65,3 \%$-a $(\mathrm{n}=264)$ heti 40 és 50 óra között dolgozik, a minta közel egyharmada $(28,5 \% ; n=115)$ kevesebb mint 40 órát. Az ügyeletek számát tekintve a minta közel fele $(49,3 \% ; n=199)$ egy ügyeletet sem vállal, 21,5\%-uk $(\mathrm{n}=87)$ legfeljebb hármat, 10,5\%-uk $(\mathrm{n}=43)$ legfeljebb ötöt, míg a minta $18,6 \%$-a $(\mathrm{n}=75)$ több mint öt ügyeletet vállal havonta.

A kiégés szempontjából fontos kérdés, hogy a magyarországi radiológiai vonatkozású munkahelyeken dolgozó szakdolgozók milyen módon próbálják bővíteni szakmai ismereteiket. A különböző képzéseken való részvétel növeli a szakmai kompetenciát, ami pozitívan hathat a személyes hatékonyságra, csökkentve ezáltal a kiégés mértékét. A válaszadók túlnyomó többsége konferenciák keretén belül mélyíti tudását $(\mathrm{n}=210)$, azonban a fóiskolai/egyetemi képzésben részt vevők száma sem elhanyagolandó $(\mathrm{n}=5 \mathrm{l})$. Az eredmények ugyanakkor felhívják a figyelmet arra, hogy a válaszadók nem tartják fontosnak a legmodernebb képalkotó technikák tanulmányozását, továbbá egyetlen válaszadó sem végez a szakterületéhez kapcsolódó kutatásokat (2. táblázat). 

\begin{tabular}{l|l} 
1. táblázat & $\begin{array}{l}\text { A válaszadók }(\mathrm{n}=404) \text { jellemzése nem, családi állapot, iskolai } \\
\text { végzettség, jelenlegi anyagi helyzet szerint }\end{array}$
\end{tabular}

\begin{tabular}{|c|c|}
\hline Nem & $\mathrm{n}(\%)$ \\
\hline Férfi & $57(14,1)$ \\
\hline Nó & $347(85,9)$ \\
\hline \multicolumn{2}{|l|}{ Családi állapot } \\
\hline Házastársával/élettársával él & $156(38,6)$ \\
\hline Házastársával/élettársával és gyerekével él & $100(24,8)$ \\
\hline Egyedülálló & $110(27,2)$ \\
\hline Egyéb családtagjával él & $28(6,9)$ \\
\hline Egyéb személlyel él & $6(1,5)$ \\
\hline Özvegy & $4(1)$ \\
\hline \multicolumn{2}{|l|}{ Legmagasabb iskolai végzettség } \\
\hline Középiskolai végzettség & $43(10,6)$ \\
\hline Felsőfokú szakképzés & $123(30,4)$ \\
\hline Főiskolai, vagy felsőfokú alapképzés (Ba/BSc) & $227(56,2)$ \\
\hline Egyetemi végzettség ( $\mathrm{Ma} / \mathrm{MSc})$ & $11(2,7)$ \\
\hline \multicolumn{2}{|l|}{ Anyagi helyzet } \\
\hline Nagyon jól megél, félre is tud tenni & $17(4,2)$ \\
\hline Megél, keveset tud félretenni & $228(56,4)$ \\
\hline Éppen megél, nem tud félretenni & $125(30,9)$ \\
\hline Nem elég a megélhetésre & $31(7,7)$ \\
\hline Rendszeres megélhetési problémái vannak & $3(0,7)$ \\
\hline
\end{tabular}

$\mathrm{Ba} / \mathrm{BSc}=$ alapképzés $(3$ év); Ma/MSc = mesterképzés (alapképzés után 2 év)

A válaszadók 30\%-a érzi azt, hogy korlátozottak a lehetőségei a szakmai munka végzése során, és szakmájuk több lehetőséget rejt magában. A válaszadók 46,5\%-a (n = 188) gondolja úgy, hogy a szakmában dolgozó radiológiai asszisztens kellő végzettséggel, kellő tapasztalattal képes lenne bizonyos orvosi feladatok ellátására (például: törések megállapítása Rtg-felvételeken, szonográfusi tevékenység). A válaszadók 79,5\%-a $(\mathrm{n}=321)$ teljes mértékben ajánlaná szakmáját a fiatal, pályaválasztás előtt álló hallgatóknak. Saját szerkesztésú kérdőívünk során nyitott kérdéseket tettünk fel a válaszadóknak azzal kapcsolatban, hogy miben látják szakmájuk gyengeségét, erősségét, továbbá mit változtatnának szakmájukban, ha lenne rá lehetőségük. A kérdéskör megfogalmazásakor nem fogalmaztunk meg előre felkínált válaszlehetőségeket, a válaszadók személyes gondolataiknak, véleményüknek adhattak hangot.

A válaszadók körében az emocionális kimerülés alskálájának átlagpontszáma $34,3(\mathrm{SD}=12,9)$, a deperszonalizációs alskáláé $12,8(\mathrm{SD}=6,6)$, míg a személyes hatékonysági alskála átlagpontszáma 41,0 $(\mathrm{SD}=8,7)$ körül alakult. Az orvosok és ápolók körében végzett Maslachkiégés kérdőív eredményeivel összevetve, a radiográfia területén dolgozó szakemberek kiégésével kapcsolatban
2. táblázat Válaszadóink munkahelyi jellege, modalitásbeli megoszlásának aránya, a szakmai kompetencia emelése érdekében tett lépések, másodállás megléte és vonatkozása

\begin{tabular}{lr}
\hline A munkahely jellege & $\mathrm{n}$ \\
\hline Egyetemi klinika & 75 \\
Megyei kórház & 113 \\
Vidéki kórház & 49 \\
Magánegészségügy & 64 \\
Járóbeteg-szakrendelő & 45 \\
Országos intézet & 58
\end{tabular}

\begin{tabular}{lc}
\hline Modalitás & 21 \\
\hline DSA & 209 \\
Rtg & 118 \\
UH & 81 \\
CT & 39 \\
MR & 63 \\
CT/MR & 12 \\
PET/Nukleáris medicina & 72 \\
Sugárterápia & 51 \\
\hline A szakmai kompetencia emelése & 159 \\
\hline Egyetemi/főiskolai képzésben vesz részt & 135 \\
Képalkotó tanfolyamokon vesz részt & 210 \\
Szakmai folyóiratot olvas & 89 \\
Konferenciákon vesz részt & 0 \\
Konferenciákon vesz részt, előadást is tart & 0 \\
Tanulmányozza a legmodernebb technikákat & \\
Kutatásokat végez & 91 \\
\hline Másodállás jelenléte & 313 \\
\hline Igen & 11 \\
Nem & \\
\hline A másodállás jellege & \\
\hline Orvosi képalkotás & \\
Egészségügy & \\
Egyéb & \\
\hline & \\
\hline
\end{tabular}

$\mathrm{CT}=$ komputertomográfia; $\mathrm{CT} / \mathrm{MR}=$ komputertomográfia $/$ mágneses rezonancia; $\mathrm{DSA}=$ digitális szubtrakciós angiográfia; $\mathrm{MR}=$ mágneses rezonancia; $\mathrm{PET}=$ pozitronemissziós tomográfia; Rtg = röntgen; $\mathrm{UH}=$ ultrahang

3. táblázat A Maslach Burnout Inventory (MBI) kérdőív átlageredményei, viszonyítva a saját kutatásunk eredményeihez az emocionális kimerülés, a deperszonalizáció és a személyes hatékonyság dimenziójában

\begin{tabular}{lccc}
\hline & MBI-átlag [9] & Saját felmérés & Cronbach-alfa \\
\hline $\begin{array}{l}\text { Emocionális } \\
\text { kimerülés }\end{array}$ & $22,0 \pm 10,8$ & $34,3 \pm 12,9$ & 0,912 \\
$\begin{array}{l}\text { Deperszonalizáció } \\
\begin{array}{l}\text { Személyes } \\
\text { hatékonyság }\end{array}\end{array}$ & $8,7 \pm 5,9$ & $12,8 \pm 6,6$ & 0,747 \\
\hline
\end{tabular}


az tapasztalható, hogy az emocionális kimerülés és a deperszonalizáció alskáláján mért értékek emelkedettebbek. A személyes hatékonyság dimenzióját vizsgálva a radiológia területén dolgozó szakemberek kedvezőbb mutatókkal rendelkeznek. A személyes hatékonysági alskálán mért enyhén magasabb érték pozitívan értelmezendő (3. táblázat).

A középiskolai, felsőfokú, foóiskolai végzettséggel rendelkezô válaszadók emocionális kimerülési átlagértéke szignifikánsan magasabb értéket mutat az egyetemi végzettséggel rendelkező válaszadókéhoz képest ( $\mathrm{p}=$ $0,001)$. A deperszonalizáció dimenziójában az egyetemi végzettséggel rendelkező válaszadók értéke bizonyult emelkedettebbnek a náluk alacsonyabb végzettséggel rendelkezókéhez képest $(\mathrm{p}=0,001)$. A munkavégzés során észlelt személyes hatékonyság átlagértékeit tekintve az iskolai végzettségtől függetlenül mindegyik kategória átlagértéke magasabb, mint a MBI során leírtak, azonban a mesterdiplomával rendelkező válaszadók értéke kiemelkedő az említett dimenzióban $(\mathrm{p}=0,008)$.

A mintánkban szereplő szakdolgozókat korcsoportok szerint kategorizáltuk. Az emocionális kimerülés és a deperszonalizáció dimenziójában a 31-35 éves válaszadók értékei meghaladják a többi korcsoportéit, az életkor előrehaladtával azonban mind az emocionális kimerülés, mind a deperszonalizáció átlagértéke mérséklődik ( $\mathrm{p}=$ $0,001 ; p=0,007)$. A személyes hatékonyság dimenziójában a 60 évnél idősebb válaszadók élik meg a legjobban a mindennapok tevékenységeit $(\mathrm{p}=0,001)$.

$\mathrm{Az}$ egészségügyben eltöltött évekre tekintettel az emocionális kimerülés dimenziójában kiugró értéket figyelhetünk meg a 16-20 éve a szakmában dolgozó válaszadóknál. Az említett érték az évek során mérséklődő tendenciát mutat a kutatásba bevont szakdolgozók körében $(\mathrm{p}=0,011)$. A deperszonalizáció dimenziójában egy szinte stagnáló emelkedett értéket fedezhetünk fel, mely érték szintén csökkenő tendenciát mutat az egészségügyi ellátásban eltöltött évek során $(\mathrm{p}=0,008)$. A személyes hatékonyság vonatkozásában kiugró és alacsonyabb értékek váltakozását figyelhetjük meg $(\mathrm{p}=0,002)$ (4. táblázat).

\section{Megbeszélés}

Számos nemzetközi kutatás irányult a radiológia területén dolgozó szakemberek körében megfigyelhető kiégésre, mely jelenség kialakulása mögött az egyik fó okként az ügyeletek magas számát nevezték meg [13-16]. Magyarországon ez idáig a kutatók kevésbé helyezték figyelmük fókuszába a radiológiai osztályokon dolgozó személyzetet. Kutatásunk ennek értelmében hiánypótlónak bizonyul, mely a magyar radiológiai osztályon dolgozó 'nondoktorok' kiégési szintjérôl kíván beszámolni. Eredményeink alapján a kutatásba bevont szakdolgozók kiégési szintje a deperszonalizáció és az emocionális kimerültség dimenzióját tekintve magasabb értéket mutat, mint a korábbi, nemzetközi tanulmányokban publikált
4. táblázat $\mid$ Az iskolai végzettség, az életkorcsoportok, az egészségügyben eltöltött évek és a kiégés kapcsolata

\begin{tabular}{|c|c|c|c|c|}
\hline Változó & $\mathrm{n}(\%)$ & $\begin{array}{l}\text { Emocionális } \\
\text { kimerülés } \\
(\text { átlag } \pm \mathrm{SD})\end{array}$ & $\begin{array}{l}\text { Deperszona- } \\
\text { lizáció } \\
\text { (átlag } \pm \mathrm{SD})\end{array}$ & $\begin{array}{l}\text { Személyes } \\
\text { hatékonyság } \\
(\text { átlag } \pm \text { SD) }\end{array}$ \\
\hline \multicolumn{5}{|l|}{$\begin{array}{l}\text { Iskolai } \\
\text { végzettség }\end{array}$} \\
\hline $\begin{array}{l}\text { Középiskolai } \\
\text { végzettség }\end{array}$ & $43(10,6)$ & $31,7 \pm 12,8$ & $12,4 \pm 7,1$ & $43,3 \pm 7,1$ \\
\hline $\begin{array}{l}\text { Felsőfokú } \\
\text { szakképzés }\end{array}$ & $123(30,4)$ & $32,1 \pm 13,1$ & $10,7 \pm 5,9$ & $41,9 \pm 9,0$ \\
\hline $\mathrm{Ba} / \mathrm{Bsc}$ & $227(56,2)$ & $36,3 \pm 12,8$ & $13,8 \pm 6,6$ & $39,9 \pm 8,7$ \\
\hline \multirow[t]{2}{*}{$\mathrm{MA} / \mathrm{MSc}$} & $11(2,7)$ & $25,9 \pm 9,4$ & $17,7 \pm 5,4$ & $45,9 \pm 8,2$ \\
\hline & & $\mathrm{p}=0,001 * *$ & $\mathrm{p}=0,001 * *$ & $\mathrm{p}=0,008^{* *}$ \\
\hline \multicolumn{5}{|l|}{ Korcsoportok } \\
\hline $20-25$ év & $40(9,9)$ & $33,3 \pm 12,1$ & $11,5 \pm 6,1$ & $40,0 \pm 9,2$ \\
\hline 26-30 év & $105(26,0)$ & $36,1 \pm 13,1$ & $14,7 \pm 5,9$ & $41,1 \pm 6,9$ \\
\hline 31-35 év & $27(6,7)$ & $40,4 \pm 9,9$ & $17,1 \pm 6,6$ & $37,3 \pm 7,8$ \\
\hline 36-40 év & $36(8,9)$ & $33,0 \pm 10,9$ & $13,1 \pm 6,4$ & $39,0 \pm 7,4$ \\
\hline $41-45$ év & $36(8,9)$ & $34,3 \pm 13,4$ & $12,0 \pm 7,9$ & $42,4 \pm 8,9$ \\
\hline 46-50 év & $65(16,1)$ & $34,7 \pm 11,9$ & $12,0 \pm 7,3$ & $40,5 \pm 9,8$ \\
\hline 51-55 év & $47(11,6)$ & $32,8 \pm 14,8$ & $10,3 \pm 4,8$ & $43,0 \pm 10,0$ \\
\hline 56-60 év & $31(7,7)$ & $32,7 \pm 15,9$ & $11,6 \pm 5,7$ & $39,6 \pm 9,7$ \\
\hline \multirow{2}{*}{$\begin{array}{l}60 \text { évnél } \\
\text { idősebb }\end{array}$} & $17(4,2)$ & $22,9 \pm 5,9$ & $9,4 \pm 6,2$ & $48,5 \pm 4,2$ \\
\hline & & $\mathrm{p}=0,001 * *$ & $\mathrm{p}=0,007^{* *}$ & $\mathrm{p}=0,001 * *$ \\
\hline
\end{tabular}

Az egészség-

ügyben

eltöltött évek

\begin{tabular}{lllll}
\hline-5 év & $114(28,2)$ & $36,5 \pm 11,8$ & $14,3 \pm 6,9$ & $41,3 \pm 7,5$
\end{tabular}

6-10 év $\quad 56(13,9) \quad 33,3 \pm 13,2 \quad 13,8 \pm 5,0 \quad 40,0 \pm 6,7$

11-15 év $26(6,4) \quad 32,6 \pm 12,2 \quad 13,1 \pm 6,2 \quad 33,7 \pm 8,1$

16-20 év $26(6,4) \quad 39,4 \pm 10,8 \quad 14,9 \pm 7,1 \quad 41,7 \pm 6,7$

21-25 év $37(9,2) \quad 35,3 \pm 11,8 \quad 11,0 \pm 7,2 \quad 44,4 \pm 8,4$

26-30 év $\quad 46(11,4) \quad 35,2 \pm 13,7 \quad 12,3 \pm 6,3 \quad 38,6 \pm 10,1$

31-35 év $53(13,1) \quad 31,2 \pm 14,1 \quad 10,5 \pm 6,5 \quad 41,4 \pm 10,6$

35 évnél $46(11,4) \quad 29,5 \pm 13,8 \quad 10,8 \pm 6,0 \quad 44,0 \pm 8,4$

több

$\mathrm{p}=0,011^{*} \quad \mathrm{p}=0,008^{* *} \mathrm{p}=0,002 * *$

*ANOVA; ** Kruskal-Wallis statisztikai elemzés során kapott eredmények

ANOVA = varianciaanalízis; $\mathrm{Ba} / \mathrm{BSc}=$ alapképzés, 3 év (régi fóiskolai diploma); $\mathrm{Ma} / \mathrm{MSc}=$ mesterképzés; $\mathrm{SD}=$ standard deviáció

értékek, a személyes hatékonyság szintje azonban nagyon kedvező tartományban mozog [17, 18].

Kutatásunk fényt próbált deríteni arra, hogy a radiográfia területén dolgozó szakemberek miben látják azokat az okokat, amelyek gyengítik a szakmájukat, egyúttal min változtatnának a szakmájukban. A válaszokat besorolásukat tekintve négy nagyobb csoportra lehetett bon- 
tani. A válaszok alapján a munkavégzéssel járó adminisztrációs feladatok és a leletezés bizonyult terhesnek a szakdolgozók számára. A kliensek és az egészségügyi ellátórendszer más szakterületen dolgozó szakemberei részéről megtapasztalt alacsony megbecsülést, az alacsony bérezést és az előrelépés lehetőségének hiányát is nehezményezték a válaszadók. Eredményeink alátámasztják az anyagi helyzetre vonatkozó frusztrációt: a minta 56,4\%-a megél ugyan a fizetéséből és keveset tud félretenni, azonban $38,4 \%$ a válaszadók közül nem tud félretenni a havi fizetéséból. A válaszadók anyagi helyzete szignifikánsan befolyásolta a deperszonalizáció, az emocionális kimerülés és a személyes hatékonyság dimenzióját $(\mathrm{p}<0,05)$. A munkavégzésért kapott jutalom és a feljebblépési lehetőség hiányát egy korábbi kutatásunk során már vizsgáltuk. E két tényező döntő befolyást gyakorolt a minta migrációs és pályaelhagyási hajlamára, jelen tanulmányunk pedig igazolta, hogy a kiégésben is szerepet játszik [19].

Eredményeink alapján a minta közel $30 \%$-a több potenciált érez szakmájában, amit az összes válaszadó további 46,6\%-a egészít ki azzal, hogy a megfelelő szintű végzettséggel rendelkező szakdolgozó kellő tapasztalattal képes lenne bizonyos orvosi feladatok ellátására. A jelen eredményekből arra a következtetésre juthatunk, hogy a radiológiai osztályok egy bizonyos szakdolgozói rétege pozitívan értékelne egy esetleges kompetenciabővítést, mely potenciális kiutat jelenthetne a kiégési szint redukálásában.

A gyakorlott radiográfusok bevonása a magasabb kompetenciát igénylő radiológiai feladatokba nem új keletű. Dániában 2013-ban publikált, a sürgősségi kórképekkel kapcsolatos kutatás rámutatott arra, hogy a radiográfusok 99\%-ban alkottak korrekt diagnózist, míg a gyakorló radiológusok 94\%-ban [20].

2012-ben Dublinban Kelly és mtsai szintén a sürgősségi kórképek között vizsgálta a fiatal radiológusok és a gyakorlott radiográfusok leletezési képességét, mely kutatás eredményéül a radiográfusok és a fiatal orvosok kollaborációja szignifikánsan magasabb diagnosztikai pontosságot mutatott [21].

Lockwood és mtsai (2015) Angliában vizsgálták az akkreditált posztgraduális koponya-CT-képzés eredményességét. A képzést elvégző radiográfusok 600 leletet készítettek, s ennek során 99\%-os szenzitivitás, 95\%-os specificitás és 90\%-os egyezségegyeztetési arány alakult ki [22]. Szintúgy Lockwood volt az, aki 2017-ben igazolta, hogy az orrmelléküreg- és arckoponya-CT-felvételek során a radiográfusok $97,5 \%$ szenzitivitást, 93,6\% specificitást és 95\%-os pontosságot képesek elérni a dedikált posztgradulális képzés után, amivel megfelelnek a magas klinikai standardoknak [23].

Piper és mtsai 2018-ban koponya- és nyakigerinc-MRfelvételeken próbálták igazolni a radiográfusok hatékonyságát. Eredményeik alapján 98,86\% szenzivitivás, $98,08 \%$ specificitás és $88,37 \%$ egyezségegyeztetési arány mutatkozott, különös figyelemmel az astrocytoma, porc- korong-protrusio, gerincvelő-kompresszió és csigolyatörés kórképeire [24].

A röntgen-, CT- és MR-képalkotás mellett szonográfusi képességeket is vizsgáltak Svédországban. A Stenman és mtsai (2013) által publikált eredmények jó interobszerver egyezséget mutattak a tapasztalt radiológusok és a radiográfusok által felismert kórképek között, kiemelkedően az epehólyag és a máj elváltozásainál [25].

A radiográfusok képességeit számos tanulmány alátámasztja, azonban szinte mindegyik az oktatás/dedikált posztgraduális képzés fontosságát helyezi a középpontba. A képzések elvégzésével a tapasztalt radiográfusok képességei megfelelőnek bizonyulnának a klinikai kihívásoknak megfelelően. Nyugati országokban bevált példa, hogy a kellő tapasztalattal és végzettséggel rendelkező radiográfusok továbbképzése során egyfajta licenszet kapnak egy adott régióban való magasabb, orvosi kompetenciák ellátására. Egy esetleges posztgraduális képzés szélesebb kompetenciát adna a vizsgált szakdolgozói körnek, feljebblépési lehetőséggel szolgálna, ami pozitív hatást gyakorolna a kiégésre, a pályaelhagyásra és a migrációs hajlamra [19, 26, 27]. Az informatikai rendszerek folytonos megújulásával párhuzamosan a mesterséges intelligencia (artificial intelligence, AI) egyre nagyobb teret hódít az egészségügyben. A radiológia területén az AI ígéretes eredményeket tudhat magáénak, melyeket jelentős izgalmak és kérdések öveznek. Könnyen elképzelhető, hogy a mesterséges intelligencia az egészségügybe való beolvadásával hatást gyakorol majd többek között a kiégés mértékére is [28].

A válaszok alapján elmondhatjuk, hogy a szakdolgozókban már megjelent az igény a saját kompetenciájuk bővítésének irányába, azonban az ehhez szükséges edukációs szint eléréséről sem szabad megfeledkezni. A válaszadók közül a minta alig több mint fele $(56,2 \%)$ rendelkezett föiskolai szintű végzettséggel, és csupán 2,7\% MSc-képesítéssel. A jelen, relatíve alacsony értékek hátterében az állhat, hogy a radiográfusképzés főiskolai szintre emelése a 2000-es évek elejére tehető, időre van szüksége a szakmának, hogy kellő szintre fejlődhessen. A tudás magasabb szintre való emelése érdekében tett erőfeszítések sem kecsegtetők, a válaszadók közül 51 ( $n=51)$ személy vesz részt fóiskolai/egyetemi képzésben, azonban senki nem végez kutatásokat tudományos területén.

Az MSc-végzettséggel rendelkező radiográfusoknak az emocionális kimerülés dimenziójában érzékelt értéke alacsonyabbnak bizonyul a náluk alacsonyabb végzettséggel rendelkezőkénél. A jelen eredményt annak tudhatjuk be, hogy az egyetemi végzettséggel rendelkező válaszadók viszonylag kevés időt töltöttek el az egészségügyben, ezért reagálhatnak emocionálisan jobban, mint társaik. A másik ok, mely a jobb érzelmi eredmények mögött állhat, az, hogy tanulmányaik során a képzésben szélesebb körü ismeretekre tesznek szert az egészségügy és a viszonyulásmenedzsment terén, ezáltal jobban kezelik az érzelmi élethelyzeteket. 
Ugyanezen csoportot vizsgálva a deperszonalizációs érték viszont szignifikánsan magasabbnak bizonyult a társakéhoz viszonyítva $(\mathrm{p}=0,001)$. A feleletválaszolós kérdésekre elvétve ugyan, de érkeztek válaszok, melyek a szakmai féltékenységet, a végzettségből adódó konfliktushelyzetet emelték ki. A jelen esetben eredményeinkből arra következtetünk, hogy a magasabb végzettséggel rendelkező radiográfusok egyfajta diszkriminációs fázison esnek át, ezért érezhetik azt, hogy az emberi kapcsolatok területén elszemélytelenednek.

A szakirodalomban egymásnak ellentmondó eredmények olvashatók az életkor, az egészségügyben eltöltött évek és a kiégés viszonylatában. Egyes tanulmányok a pályakezdők korosztályát találták veszélyeztetettnek, mások pedig a tapasztaltabb korosztályt. Számos tanulmány a fokozott fizikai és érzelmi megterhelést, a felelősséget és az alváshiányt tartja a fiatal munkaerő fokozott kiégésének hátterében. Az eredmények szerint a pályakezdő szakdolgozók körében a legalacsonyabb a kiégés és az elégedettség, míg a 10-20 éve az egészségügyben dolgozók értéke a legmagasabb [29-32]. Jelen tanulmányunk során az emocionális kimerülés és a deperszonalizáció-dimenziókban az életkor viszonylatában a kezdeti éveket követően folyamatosan emelkedő értékeket figyelhetünk meg. A válaszadók 35. életévét követően az említett két dimenzió átlagértéke folyamatosan csökkenő tendenciát mutat, mely értékek hátterében a munkakörbe való beleszokás és a munkakörnyezet elfogadása játszhat szerepet. A személyes hatékonyság dimenziójában tapasztalt átlagérték a 31-35 éves szakdolgozók csoportjánál kissé alacsony értéket mutat a többi korcsoport értékéhez képest, azonban a jelen érték még így is magasan meghaladja az MBI-átlagértéket. Ugyanezen jellegzetesség figyelhető meg a 11-15 éve az egészségügyben dolgozók csoportjánál is. Az alacsonyabb érték hátterében a deperszonalizáció és az emocionális kimerülés dimenziójához hasonlóan a munkakörnyezet megszokása állhat, mely érzet során hajlamosak vagyunk az esetleges pozitív visszajelzéseket kevésbé érzékelni, megszokottnak véljük azokat. Az egészségügyben eltöltött évek a deperszonalizáció és az emocionális kimerülés dimenziójának kezdeti emelkedett értékeinek enyhe csökkenése után egy újabb kicsúcsosodás jellemző a 16-20 éve az egészségügyi pályán lévő válaszadók között. Az értékek az évek haladásával csökkennek, mely jelenség hátterében meghúzódó okok vizsgálata további kutatásokat igényel.

A kiégés jelenségének megelőzése világszerte az egyik legnagyobb kihívást jelentő probléma; számos, kiégést megelőző program indult útjára, melyek sikerességét kutatási eredmények támasztják alá. A kiégés prevenciója szempontjából a megoldás szervezeti vagy egyéni szintú lehet. Az egészségügyi ellátórendszer szervezeti szinten jobb munkafeltételeket biztosíthat, a munkahelyi stressz kezelésében nyújthat segítséget, továbbá folyamatos fejlődési lehetőségeket biztosíthat. A radiológiai osztályok múködése során háttérbe szorult az osztályértekezletek, teammegbeszélések fontossága. Az osztályértekezletek kiváló lehetőséget teremtenek többek között a problémák felvetésére, a brainstorming vagy más problémamegoldó, szinte minden szakdolgozó véleményét figyelembe vevő módszer alkalmazható az adott probléma megoldására. A szakdolgozók sokszor akár tájékozatlannak is vélhetik magukat, aminek oka feltehetően a kellő mértékű és minőségű kommunikáció hiánya vezető és beosztott között. Az egyéni szintú stresszkezelésben többek között a relaxációs technikák, az önfejlesztés és az önismeret növelése, a stresszoldó technikák gyakorlása, valamint a testmozgás is a munkavállaló segítségére lehet [33].

\section{Következtetés}

Kutatásunk egy eddig még kevéssé vizsgált területet helyez fókuszába magyarországi viszonylatban. Az orvosi képalkotás segítségét számos páciens veszi igénybe, gondolva itt a legkisebb traumáktól egészen a komoly operációk utánkövetésére. A radiológiai osztályokon dolgozó szakdolgozók az átlagnál magasabb deperszonalizációs és emocionális kimerülési értékekkel bírnak, ami összefüggést mutat részben az egészségügyben eltöltött idővel és az életkorral. A személyes hatékonyság dimenziójában mért magasabb skálaértékek hátterében a páciensektől és munkatársaktól kapott visszajelzés pozitív hatása állhat. A deperszonalizáció és az emocionális kimerülés dimenzióinak emelkedett értéke, továbbá a relatíve magas átlagéletkor figyelmeztető jel lehet a munkáltatók számára a változás irányában. A munkavállaló mint egyén a személyes kompetenciáinak fejlesztésében találhatja meg a megoldást a kiégés szintjének mérséklésére, legyen az egyetemi képzésekben, kutatásokban, oktatásban, konferenciákon való részvétel. A kapott eredményeink jól korrelálnak a nemzetközi kutatások eredményeivel, kutatásaink azonban a jövőben mélyebbre kell, hogy hatoljanak a jelenség mögött húzódó okok felderítésére.

Anyagi támogatás: A közlemény megírása anyagi támogatásban nem részesült.

Szerzői munkamegosztás: S. D.: Ötletgazda, kivitelezés, a kézirat elkészítése. V. V.: A kézirat elkészítése. P. A. A.: A kézirat elkészítése, adatfeldolgozás. K. A.: Adatfeldolgozás. P. Cs. M.: Statisztikai elemzés. Cs. Sz.: A kézirat elkészítése, kérdőívek. B. J.: Lektorálás, szerkesztés. M. M.: Lektorálás, szerkesztés. R. I.: Lektorálás, szerkesztés. K. Á.: Lektorálás, szerkesztés. A cikk végleges változatát valamennyi szerző elolvasta és jóváhagyta.

Érdekeltségek: A szerzőknek nincsenek érdekeltségeik. 


\section{Irodalom}

[1] Akroyd D, Caison A, Adams RD. Burnout in radiation therapists: the predictive value of selected stressors. Int J Radiat Oncol Biol Phys. 2002; 52: 816-821.

[2] Maslach C, Schaufeli W, Leiter M. Job burnout. Annu Rev Psychol. 2001; 52: 397-422.

[3] Probst H, Griffiths S, Adams R, et al. Burnout in therapy radiographers in the UK. Br J Radiol. 2012; 85: e760-e765.

[4] Chiesa A, Serretti A. Mindfulness-based stress reduction for stress management in healthy people: a review and meta-analysis. J Altern Complement Med. 2009; 15: 593-600.

[5] Ugwu AC, Egwu OA, Ochie K, et al. Incidence of occupational stress among medical radiographers: a population based zonal survey. Niger J Physiol Sci. 2007; 22: 123-127.

[6] Shanafel TD, Sloan JA, Habermann TM. The well-being of physicians. Am J Med. 2003; 114: 513-519.

[7] Querios C, Carlotto MS, Kaiseler M, et al. Predictors of burnout among nurses: an interactionist approach. Psicothema 2013; 25: 330-335.

[8] Fusz K, Pakai A, Kívés Zs, et al. Work schedules in the Hungarian health care system and the sleep quality of nurses. [Munkarendek a hazai egészségügyi rendszerben, és az ápolók alvásminősége.] Orv Hetil. 2016; 157: 379-384. [Hungarian]

[9] Maslach C, Jackson SE, Leiter M, et al. Maslach Burnout Inventory Manual. Consulting Psychologist Press, Palo Alto, CA 1996.

[10] West CP, Dyrbye LN, Satele DV, et al. Concurrent validity of single-item measures of emotional exhaustion and depersonalization in burnout assessment. J Gen Intern Med. 2012; 27: 14451452.

[11] Palfi I, Nemeth K, Kerekes Zs, et al. The role of burnout among Hungarian nurses. Int J Nurs Pract. 2008; 14: 19-25.

[12] Bencés I. Nurses and burnout. [Az ápolók és a kiégés.] Nővér 2006, 19(3): 10-16. [Hungarian]

[13] Hall-Kenyon KM, Bullough RV, MacKay LK, et al. Preschool teacher well-being: a review of the literature. Early Childhood Educ J. 2014; 42: 153-162.

[14] Győrffy Z, Girasek E. Burnout among Hungarian physicians. Who are the most jeopardized? [Kiégés a magyarországi orvosok körében. Kik a legveszélyeztetettebbek?] Orv Hetil. 2015; 156: 564-570. [Hungarian]

[15] Mackay SJ, Baker R, Collier D, et al. A comparative analysis of emotional intelligence in the UK and Australian radiographer workforce. Radiography 2013; 19: 151-155.

[16] Hutton D, Probst H, Patel I, et al. OC-0560: Job satisfaction of the UK radiotherapy workforce: physics and radiography, a strategy to improve satisfaction. Radiother Oncol. 2013; 106(Suppl 2): S214-S215.

[17] Singh N, Wright C, Knight K, et al. Occupational burnout among radiation therapists in Australia: findings from a mixed methods study. Radiography 2017; 23: 216-221.

[18] Girgis A, Hansen V, Goldstein D. Are Australian oncology health professionals burning out? A view from the trenches. Eur J Cancer 2009; 45: 393-399.
[19] Sipos D, Vandulek Cs, Petone Csima M, et al. The attrition and migration behaviour among Hungarian radiographers. Glob J Health Sci. 2017; 10: 1.

[20] Buskov L, Abild A, Christensen A, et al. Radiographers and trainee radiologists reporting accident radiographs: a comparative plain film-reading performance study. Clin Radiol. 2013; 68: $55-58$.

[21] Kelly BS, Rainford LA, Gray J, et al. Collaboration between radiological technologists (radiographers) and junior doctors during image interpretation improves the accuracy of diagnostic decisions. Radiography (Lond). 2012; 2: 90-95.

[22] Lockwood P, Piper K, Pittock L. CT head reporting by radiographers: results of an accredited postgraduate programme. Radiography (Lond). 2015; 21: e85-e89.

[23] Lockwood P. CT sinus and facial bones reporting by radiographers: findings of an accredited postgraduate programme. Dentomaxillofac Radiol. 2017; 46: 20160440.

[24] Piper K, Pittock L, Woznitza N. Radiographer reporting of neurological magnetic resonance imaging examinations of the head and cervical spine: findings of an accredited postgraduate programme. Radiography 2018; 24: 366-369.

[25] Stenman C, Jamil S, Thorelius L, et al. Do radiologists agree on findings in radiographer-acquired sonographic examinations? J Ultrasound Med. 2013; 32: 513-518.

[26] West CP, Shanafelt TD, Kolars JC. Quality of life, burnout, educational debt, and medical knowledge among internal medicine residents. JAMA 2011; 306: 952-960.

[27] Oláh A, Máté $\mathrm{O}$, Betlehem J, et al. The international practice and acceptation concept on Hungary of the Advanced Practice Nurse (APN) training on the MSc level. [Advanced Practice Nurse (APN) MSc képzés bevezetése Magyarországon.] Nővér 2015; 28(2): 3-10. [Hungarian]

[28] Syed AB, Zoga AC. Artificial intelligence in radiology: current technology and future directions. Semin Musculoskelet Radiol. 2018; 22: 540-545.

[29] Dyrbye LN, Varkey P, Boone SL, et al. Physician satisfaction and burnout at different career stages. Mayo Clin Proc. 2013; 88: 1358-1367.

[30] Aminazadeh N, Farrokhyar F, Naeeni A. Is Canadian surgical residency training stressful? Can J Surg. 2012; 55: S145-S151.

[31] Tyssen R, Vaglum P. Mental health problems among young doctors: an updated review of prospective studies. Harv Rev Psychiatry 2002; 10: 154-165.

[32] Ádám Sz, Torzsa P, Győrffy Zs, et al. Frequent occurance of level burnout among general practitioners and residents. [Gyakori és magas fokú kiégés a háziorvosok és a háziorvosi rezidensek körében.] Orv Hetil. 2009; 150: 317-323. [Hungarian]

[33] Regehr C, Glancy D, Pitts A, et al. Interventions to reduce the consequences of stress in physicians: a review and meta-analysis. J Nerv Ment Dis. 2014; 202: 353-359.

(Sipos Dávid, Kaposvár, Szent Imre u. 14/B, 7400 e-mail: cpt.david.sipos@gmail.com)

A cikk a Creative Commons Attribution 4.0 International License (https://creativecommons.org/licenses/by/4.0/) feltételei szerint publikált Open Access közlemény, melynek szellemében a cikk bármilyen médiumban szabadon felhasználható, megosztható és újraközölhetö, feltéve, hogy az eredeti szerző és a közlés helye, illetve a CC License linkje és az esetlegesen végrehajtott módositások feltüntetésre kerülnek. (SID_1) 